\section{Constitutive expression of a synthetic cry $1 A b$ gene confers resistance to potato tuber moth (Phthorimaea operculella Zeller) larva}

\author{
Hamed Salehian ${ }^{1,2}$, Hassan Rahnama ${ }^{2 *}$, Sara Dezhsetan ${ }^{1}$ and \\ Saeid Babaei ${ }^{2}$
}

\begin{abstract}
The potato tuber moth (Phthorimaea operculella Zeller) (PTM) is a destructive potato pest. Bacillus thuringiensis cry genes encode crystal proteins that have toxic characteristics against PTM. The aim of the present study was to develop a PTM resistant potato CV. Agria using the synthetic Bt cry 1 Ab gene. The transformation vector was constructed by inserting the cry $1 \mathrm{Ab}$ gene into the pBI121 binary expression vector. The Agrobacterium tumefaciens strain AGL1 harboring the $\mathrm{pBI} 35 \mathrm{SC}$ ry $1 \mathrm{Ab}$ construct was used for potato transformation. The results indicated that out of 97 putative transformed lines, 30 lines were PCR positive. Southern blot analysis revealed that one to three copies of transgenes were inserted into transgenic lines. The immunoassay test revealed the expression of the Cry protein. Furthermore, the results of bioassays confirmed the high mortality level of neonate larvae. The results of this study suggested that the transgenic lines have significant potential in pest control.
\end{abstract}

Keywords: Bacillus thuringiensis, cry proteins, potato tuber moth (PTM), Solanum tuberosum, transgenic plant.

\section{INTRODUCTION}

Potato (Solanum tuberosum L.) is the most important non-cereal crop in the world. A wide range of insects can damage potato crops, either directly, through feeding on tubers, or indirectly, by feeding on leaves or stems. Potato tuber moth (Phthorimaea operculella Zeller.) (PTM) is one of these insect pests, which can completely destroy the crop if left uncontrolled. PTM is cosmopolitan in distribution and currently found in over 90 countries in temperate and tropical regions. Adult PTMs are weak fliers, so the global distribution and range expansion of PTM is likely largely due to movement of larvae-infested seeds (Kroschel and Schaub 2013). PTM is typically a leafminer, which seldom causes economically important damage in potato. When foliage grows old or is killed with crop desiccants prior to harvest, larvae will fall to the soil and feed on potato tubers, which is where considerable economic damage occurs. When infested tubers are harvested, larvae can develop and further damage can occur to tubers in storage. PTM is thus a significant problem in potato growing and in potato storage (Kumar et al. 2010, Navarre and Pavek 2014). Product losses up to $100 \%$ have been reported in some cases, especially where warehouses are not refrigerated (Kroschel and Schaub 2013).
Crop Breeding and Applied Biotechnology 21(1): e31292119, 2021 Brazilian Society of Plant Breeding. Printed in Brazil http://dx.doi.org/10.1590/198470332021v21n1a9

70332021v21n1ag 
Adult PTM insects lay their eggs on green foliage over potato tubers or in the soil. Newly hatched larvae create tunnels in the mesophyll and cause leaf damage by mining in the leaf midrib. Prior to potato harvest, larvae drop to the soil and feed on tubers. This feeding reduces the quantity and quality of the harvested potatoes. When tubers are infested, damage increases rapidly during the storage period (Kumar et al. 2010) and this larval damage makes tubers unsuitable for human consumption. PTM infestation creates an excellent opportunity for infestation of other pests and pathogens (Mohammed et al. 2000).

Chemical control has been one of the most widely used pest management strategies in potato production over the past century. Because of the adverse effects of this chemical control on the environment and on human health, effective non-chemical tactics based on natural materials have been developed to control this pest (Lacey and Kroschel 2006, Damalas and Eleftherohorinos 2011). Developments in the tissue culture, genetic transformation, and genomics fields have led to recent pest-control strategies based on the use of resistant transgenic plants. These strategies consist of integrating specific genes that encode resistance factors into the genome of the potato plant. These novel genes can come from diverse sources, including wild Solanum species (Sagredo et al. 2006) or bacteria (Mohammed et al. 2000). While traditional breeding methods are restricted to introgression of genes from closely related species, genetic transformation greatly increases potential new sources of resistance. Bacillus thuringiensis (Bt) produces a Cry protein that interacts with specific protein receptors in the insect midgut, causing death of the target pest (Vreugdenhil et al. 2007, Zhang et al. 2016, Chattopadhyay and Banerjee 2018). Various Bt genes (cry1Aa, cry1Ab, and cry1Ac) have been used to provide stable resistance against the PTM for several potato varieties (Naimow et al. 2003, Estrada et al. 2007). Also, the cry1la1 (cry5) gene significantly reduced PTM damage to potato plants in field trials and in stored potato tubers compared to non-transgenic control plants and tubers (Mohammed et al. 2000, Douches et al. 2002, Veale et al. 2012) . Integrated pest management practices, including the use of Genetically Modified (GM) resistant varieties and suitable pre- and post-harvest training, are most important in newly colonized areas where PTM is not completely established (Pacifico et al. 2019). This approach prevents or reduces the need to use chemical pesticides, an approach linked to sustainable agriculture, especially organic growing, where insecticides are prohibited (Pacifico et al. 2019).

Various Bt transgenic potato lines have been developed that express cry genes and produce a considerable amount of Cry proteins that are effective enough for insect pest management under field conditions (Chakrabarti et al. 2000, Ghasimi hag et al. 2009, Mehrotra et al. 2011). Laboratories in several countries have developed insect-resistant transformed potatoes; however, there is currently no commercial use of transgenic potatoes. Development of Bt potatoes that provide resistance to PTM along with high crop yield could lead to a reduction in the cost of potato production. In previous decades, Morfona was the potato variety most grown in Iran, but in recent years, Iranian farmers have shifted to use of mini-tubers of the Agria variety because of its high yield and adaptability. Currently, Agria is the most common potato variety in Iran. Yet, with importation of plants and their products comes the risk of introducing weeds, pests, and diseases. They can threaten the natural environment, food security, and the economy of Iran. Thus, the aim of the present study was to develop Bt transgenic potato resistant to PTM. PTM is one of the most important problems in potato production and has thus driven the focus on transformation of potato using the synthetic Bt cry1Ab gene.

\section{MATERIAL AND METHODS}

\section{Vector construction}

The sequence encoding the $c r y 1 A b$ synthetic insecticidal gene, along with the 355 terminator, was excised from the pCIB4421 plasmid (Ghareyazie et al. 1997) using BamHI and EcoRI restriction enzymes. It was then ligated in the same restriction enzyme sites of the pBI121 binary vector (Figure 1). The new binary vector pBI35SCry1Ab construct contained a npt/l gene as a selectable marker. Finally, the freeze-thaw method was used to transform the constructed binary vector pBI35SCry1Ab into the A. tumefaciens strain AGL1 (Ghasimi hag et al. 2009).

The A. tumefaciens strain, harboring pBI35SCry1Ab, was grown overnight in a Lysogeny broth (LB) medium complemented with $50 \mathrm{mg} \mathrm{L}^{-1}$ kanamycin and $50 \mathrm{mg} \mathrm{L}^{-1}$ rifampicin. Agrobacterium-mediated transformation of potato explants was conducted by a diluted overnight agrobacterium solution (Mi et al. 2015). 


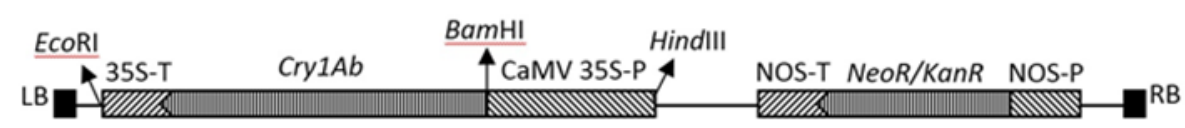

Figure 1. Schematic presentation of the plant transformation vector $\mathrm{pBI} 35 \mathrm{SCry} 1 \mathrm{Ab}$ : T-DNA region containing the $c r y 1 \mathrm{Ab}$ gene under the control of the CaMV 35S promoter and 35S terminator. The base vector is the binary pBI121 plasmid. The Kanamycin resistance (nptII) gene was used for in vitro plant screening. EcoRI, BamHI, and HindIII show the enzyme restriction sites. From right to left - RB: right border; NOS-P: nopaline synthase promoter; NeoR/KanR: kanamycin resistance gene; NOS-T: nopaline synthase terminator; CaMV 35S-P: cauliflower mosaic virus promoter; cry1Ab: transgene; 35S-T: cauliflower mosaic virus terminator; LB: left border.

\section{Plant materials and transformation protocol}

The in vitro virus-free plants of potato cv. Agria were used for plant transformation. The terminal buds of potato plants were used for in vitro proliferation. For this purpose, $1-2 \mathrm{~cm}$ of shoot-ends were cultured in liquid Murashige and Skoog (MS) medium (Murashige and Skoog 1962) including vitamins (Duchefa). The cultured shoot-ends were then incubated in a phytotron room which was set for 25 으 and a 16/8 h light/dark cycle. Internodal stem segments (5-6 $\mathrm{mm}$ ) were excised from the four-week-old shoots and were used for co-cultivation with agrobacterium.

MS medium including vitamins (Duchefa) supplemented with benzylaminopurine $\left(1.0 \mathrm{mg} \mathrm{L}^{-1}\right)$, gibberellic acid $(0.2$ $\left.\mathrm{mg} \mathrm{L}^{-1}\right)$, zeatin riboside $\left(1.0 \mathrm{mg} \mathrm{L}^{-1}\right)$, 1-naphthaleneacetic acid $\left(0.02 \mathrm{mg} \mathrm{L}^{-1}\right)$, sucrose $\left(30 \mathrm{~g} \mathrm{~L}^{-1}\right)$, and phytoagar $\left(8 \mathrm{~g} \mathrm{~L}^{-1}\right)$ was used as a one-step regeneration medium. Before the inoculation, explants were incubated at 24 으 for two days. The single colony of Agrobacterium (AGL1) harboring the constructed binary vector was grown at 28 을 overnight at $200 \mathrm{rpm}$ in LB complemented with $50 \mathrm{mg} \mathrm{L}^{-1}$ kanamycin and $50 \mathrm{mg} \mathrm{L}^{-1}$ rifampicin antibiotics. The freshly grown Agrobacterium was diluted at the ratio of 1:5 using fresh LB. It was then supplemented with $74 \mathrm{mM}$ acetosyringone (Chetty et al. 2015). The Agrobacterium strain and internodal explants were co-cultivated for 5-10 minutes at $75 \mathrm{rpm}$ under sterile conditions. The inoculated internodal stem segments were placed on sterile Whatman filter paper to drain the excess culture medium. Subsequently, the explants were returned to the preculture medium and co-cultivated for 2 days. After that, they were transferred to the selection medium composed of preculture medium supplemented with cefotaxime (200 $\left.\mathrm{mg} \mathrm{L}^{-1}\right)$ and kanamycin sulfate $\left(50 \mathrm{mg} \mathrm{L}^{-1}\right)$.

\section{Screening of putative transformants using PCR analysis}

Total genomic DNA from leaves of putative transgenic lines, as well as one non-transgenic plant as a negative control was extracted using the CTAB method. The Polymerase Chain Reaction (PCR) method with specific primers for cry $1 A b$ (F-5' ATCGAGACCGGCTACACCC $3^{\prime}$ and R-5' GAGGTGGCACGTTGTTGTTC $3^{\prime}$ ), and nptII (F-5' GCTATTCGGCTATGACTGGGCAC $3^{\prime}$ and R-5' TCATCCTGATCGACAAGACCGGC 3'), and 35S CaMV (F-5' GCTCCTACAAATGCCATC 3' and R-5' GATAGTGGGATTGTGCGTC $3^{\prime}$ ) genes was carried out using bioFACT PCR kit. VirG specific primers (F-5' ATGATTGTACATCCTTCACG 3' and R-5' TGCTGTTTTTATCAGTTGAG $3^{\prime}$ ) used to confirm that putative lines are free of Agrobacterium contamination. Transformation efficiency was calculated as the ratio of transgenic plants to total regenerated plants.

\section{Southern blot analysis}

The real integration of the transgene in the putative plant genome was analyzed by Southern blotting. About 60 $\mu \mathrm{g}$ of genomic DNA from transgenic and non-transgenic plants was digested with HindlII. This enzyme was cut in the $\mathrm{pBI} 35 \mathrm{SC}$ ry1Ab construct only once. DNA fragments were separated via electrophoresis on $1 \%$ agarose gel, after which they were blotted onto a nylon membrane (Roche, Germany) using the capillary transfer method (Sambrook and Russell 2001). The PCR DIG Probe Synthesis Kit (Roche, Germany) was used to label cry1Ab fragments with DIG-dUTP to be used as a probe in the hybridization stage. The instruction manual of DIG DNA labeling and detection kit (Roche, Germany) was followed for stringency wash and transgene detection steps.

\section{Reverse Transcription PCR (RT-PCR)}

To evaluate gene expression at the transcriptional level, RNA extraction from transgenic plants was performed using TriPure Isolation Reagent (Roche. Cat. No. 11667157 001) according to the kit manual. RT-PCR reactions were 
performed using the Titan One Tube RT-PCR kit (Roche. Cat. No. 11939823 001). The cDNA synthesis from both mRNA and PCR were performed in a $250 \mu \mathrm{L}$ tube in the Bio Rad iCycler thermal cycler (USA). The primers used at this stage for the cry $1 A b$ gene were the same as the primers used in PCR. The $\beta$-actin gene was used as an endogenous control in all RT-PCRs. Total RNA extracted from $100 \mathrm{mg}$ of leaf tissues was reverse transcribed into CDNA and used as a template in RT-PCRs with cry $1 A b$ and 8 -actin specific primers (F-5' CCAAGGCCAACCGCGAGAAGATGAC 3' and R-5' AGGGTACATGGTGGTGCCGCCAGAC $3^{\prime}$ ). Reverse transcription reactions were performed at 50 으 for 30 min and initial denaturation at $95{ }^{\circ} \mathrm{C}$ for 5 min followed by 35 amplification cycles, each consisting of 1 min of denaturation at $95^{\circ} \mathrm{C}, 1$ min of annealing at $58^{\circ} \mathrm{C}$, and $1 \mathrm{~min}$ of extension at $72{ }^{\circ} \mathrm{C}$, followed by a final extension of $5 \mathrm{~min}$ at $72{ }^{\circ} \mathrm{C}$. The RT-PCR products were separated by $1 \%$ agarose gel electrophoresis.

\section{Cry1Ab protein detection}

The Cry1Ab/Ac ImmunoStrip (Agdia Inc., IN, USA) kit was used to quickly determine the expression of the Cry1Ab protein both in the putative transgenic lines and in the non-transgenic control plant. The total protein extraction was performed using green leaves of eight-week-old greenhouse potato plants, according to the kit manual. For the solid materials to sediment, tubes were left at rest for 2 minutes before insertion of the immunostrip in the extract solution. The final results were interpreted 10 minutes after the development of bands on the strips.

\section{Bioassay}

Neonate larvae of PTM were used to conduct bioassays on detached leaves. The eggs of PTM were provided by the Iranian Research Institute of Plant Protection (IRIPP). The insects were reared according to the method described by Mohammed et al. (2000). After mating, adult moth females laid their eggs on the filter paper.

Six PCR positive lines were selected based on phenotypic traits for bioassays of detached leaves. A non-transgenic plant was used as a control plant. Cotton was soaked in water and placed in a $1.5 \mathrm{ml}$ vial. Next, petioles of the youngest fully expanded leaves were inserted in the soaked cotton (Figure 5B and 5C). Ten neonate PTM larvae were placed on each leaf then placed in a Petri dish. The whole system was sealed with parafilm (Estrada et al. 2007, Ghasimi Hagh et al. 2009). and the Petri dishes were kept under controlled conditions (room temperature $24 \pm 1$ 으 $\mathrm{C}$ with a $16 / 8 \mathrm{~h}$ photoperiod). This test was replicated 3 times for each line. The mortality rate and leaf damage percentages were recorded at 3 and 6 days after infestation. The percentages of leaf damage were estimated through visual scoring. All ten larvae in each Petri dish were weighed at six days after infestation.

\section{RESULTS AND DISCUSSION}

\section{Potato transformation}

Benefits of GM crops include reduced production costs, increased crop yields, reduced need for pesticides, enhanced nutrient composition and food quality, resistance to pests and disease, greater food security, and medical benefits for a growing world population (Phillips 2008). Introducing transgenes in the nuclear genome of plants using Agrobacterium-based plasmid vectors have caused transformation of a wide range of plant species (Meiyalaghan et al. 2010). Agrobacterium-mediated transformation of potato, selection based on kanamycin resistance, and use of the nptll selectable gene marker have proven to be an effective technique for transferring Bt genes (Kumar et al. 2010).

The $\mathrm{pBI} 35 \mathrm{SCry} 1 \mathrm{Ab}$ transformation vector with the $\mathrm{pBI} 121$ backbone and codon-optimized cry $1 \mathrm{Ab}$ gene flanked by the $35 \mathrm{SCAMV}$ promoter and $35 \mathrm{~S}$ terminator was used for potato transformation. Internodal stems cut from four-week-old potato cv. Agria were used as explants (Figure 2A). One week after transferring the agrobacterium-inoculated intermodal explants to the selection medium, calli formed at both cut edges of the explants (Figure 2B). Within 4-6 weeks, kanamycinresistant shoots emerged from the hard and compact calli on the intermodal explants (Figure 2C). The selection medium was used for initial screening of the putative transformants. The selection agent caused limited regeneration only in the transformed shoots. Finally, 97 putative transgenic potato shoots were obtained from 400 internode segments infected with Agrobacterium. All of the excised individual shoots were then transferred to a root induction medium under in vitro controlled conditions (Figure 2D). After acclimatization, plantlets were grown in pots in a greenhouse (Figure 2E, 


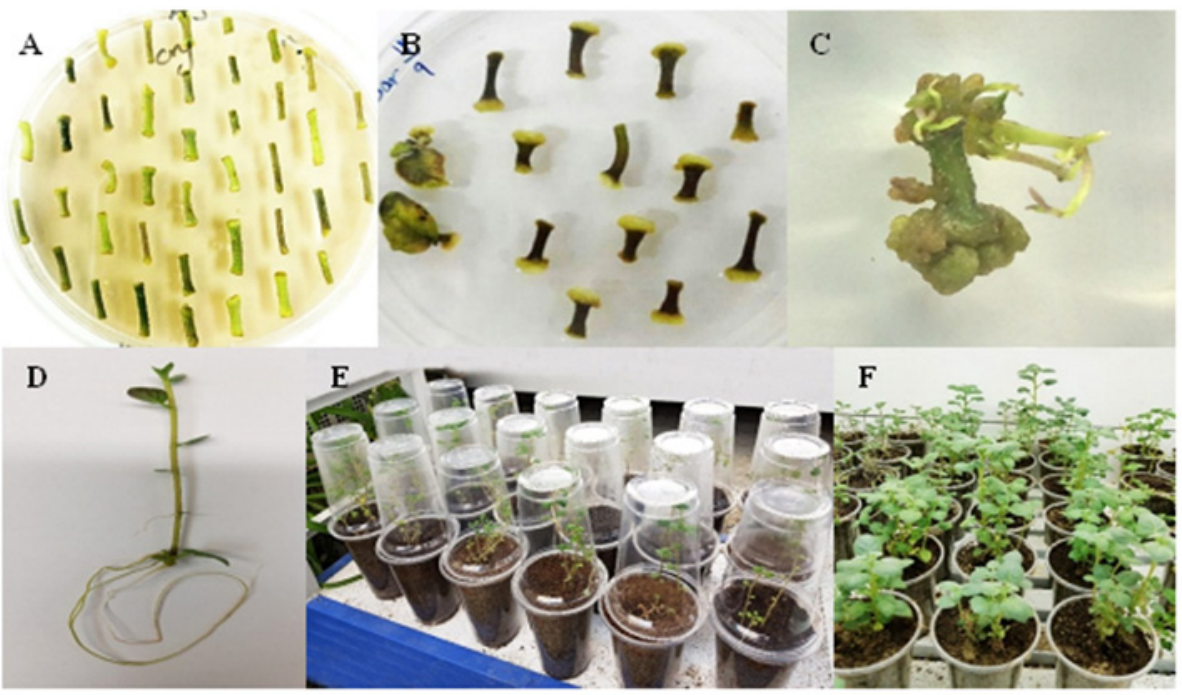

Figure 2. Different stages of genetic transformation of potato Agria cv. by Agrobacterium tumefaciens. A: co-culture of explants and $c r y 1 A b$ harboring Agrobacterium; B: initial callus induction on optimized regeneration-selection media; C: regeneration of putative transgenic shoots; D: root induction in regenerated plantlets; E: plantlet acclimatization in growth chamber; F: transgenic plants in the greenhouse.

2F). The high initial concentration of the selection agent would be enough to eliminate untransformed shoots, but low concentrations would provide an appropriate environment to allow rapid recovery and regeneration of transformed lines (Barrell et al. 2002). In this study, the initial concentration of the selection agent allowed rapid regeneration time (6 weeks), with a relatively low occurrence of escaped plants.

\section{PCR analysis of putative transformants}

Secondary screening of the 97 putative transformed lines was carried out using PCR analysis by the 35S CaMV, cry $1 A b$, and $n p t / l$ specific primers. PCR analysis revealed that a total of 30 out of 97 putative transgenic lines produced specific bands for all the primers tested (Figure 3). Transformation efficiency (calculated as the ratio of transgenic plants to the total of regenerated plants) was $30.92 \%$. To confirm that these putative lines were free of Agrobacterium contamination, PCR-positive lines were tested for the presence of VirG specific bands. All these putative lines were identified as VirG PCR- negative transgenic lines (Figure 3D). The remaining 67 lines were PCR-negative in PCR analysis. These lines were considered to have escaped from the kanamycin primary filter and were thus removed from subsequent analysis. PCR analysis for both cry $1 A$ and nptll genes confirmed that 30 out of 97 regenerated potato lines were transgenic. Thus, in this study, the transformation efficiency was $30.92 \%$. Other researchers have reported lower numbers; for example, Guo et al. (2016) reported 2.15\%, while Kamionskaya et al. (2012) reported 9.3\% and 20.8\% transformation rates for two different potato varieties.

\section{Southern genomic hybridization analysis}

In order to confirm the integration of the T-DNA transformation cassette in the genome of potato lines, Southern blot analysis was implemented on 24 transgenic lines that were selected based on PCR analysis. Hybridization of the probe to undigested DNA indicated that at least one copy of the cry $1 A b$ gene was inserted in the genome of transgenic potato plants (data not shown).

The hybridization was carried out with single-digested DNA using HindIII. We observed that the band patterns were within 3-9 kb (Figure 3E). Different sizes of bands revealed that transgenic plants emerged from independent cells in the selective medium. Thus, it can be concluded that the copy of the cry $1 \mathrm{Ab}$ gene was integrated randomly in the genomes of individual lines. Based on Southern blot analysis, 21 out of 24 lines were independent events, with 1-4 copies of transgenes. Furthermore, some of the transgenic lines (e.g., lines PC1-11 and PC1-12) indicated the same pattern in the 

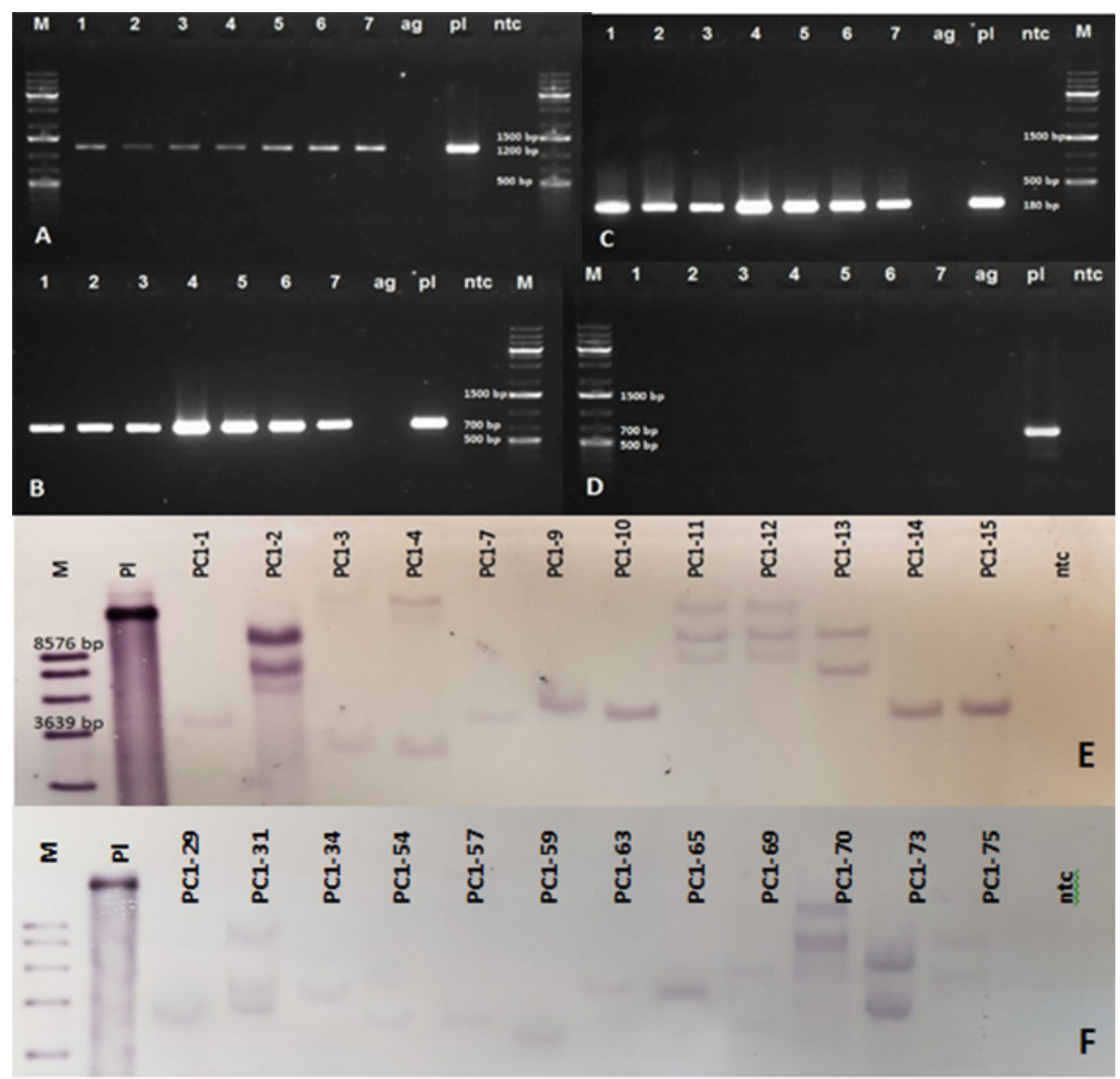

Figure 3. Amplification of A: cry1Ab gene; B: nptll gene; C: $35 S$ CaMV fragment; D: VirG fragment by specific primers. Lane M: 1 Kb plus ladder; 1-7: putative transformants; pl: pBI35SCry1Ab plasmid; ntc: non-template control. E and F: Southern blot analysis of transgenic potato lines. The probe used for hybridization was a Dig-labeled denatured 1190-bp DNA fragment corresponding to the $c r y 1 A b$ gene sequence. Lane M: DNA molecular weight marker VII Dig-labeled (Roche); pl: pBI35SCry1Ab plasmid; PC1-1 to PC1-75: transgenic potato lines digested with HindIII; ntc: non-transgenic control.

Southern blot hybridization, which were grouped as the same transgenic events (Figure 3E). In the present study, one copy of transgene was detected in 12 events of transgenic potato plants.

\section{Expression of the cry1Ab gene in transgenic plants}

RT-PCR with cry1Ab specific primers resulted in a positive amplicon of $1190 \mathrm{bp}$ fragments corresponding to the requisite size in the transgenic lines (Figure 4). The results show that the cry1Ab gene is expressed at the transcriptional level.

\section{Cry1Ab protein detection by immunostrip test analysis}

The expression of the Cry1Ab protein in the leaves of 21 independent transgenic lines was detected by the immunostrip test. The absence of this protein in non-transgenic control lines confirmed the correctness of the results. Beissinger and Inglis (2018) used both rapid (immunostrips) and common (ELISA) detection methods for potato virus Y. They reported a total of 100 and 103 out of 240 inoculated samples were positive using the immunostrips and ELISA, respectively. Ghasimi Hagh et al. (2009) used immunostrips for detecting Cry1Ab proteins in transgenic potato lines. Davidson et al. (2002) reported that despite different levels of Cry protein expression, the transgenic lines exhibited similar levels of resistance to lepidopteran pests. In addition, Meiyalaghan et al. (2006) reported that transgenic potatoes harboring cry $1 A c 9$ and cry9Aa2 genes exhibited $51 \%$ and $84 \%$ resistance to the PTM fed with excised greenhouse-grown leaves. 


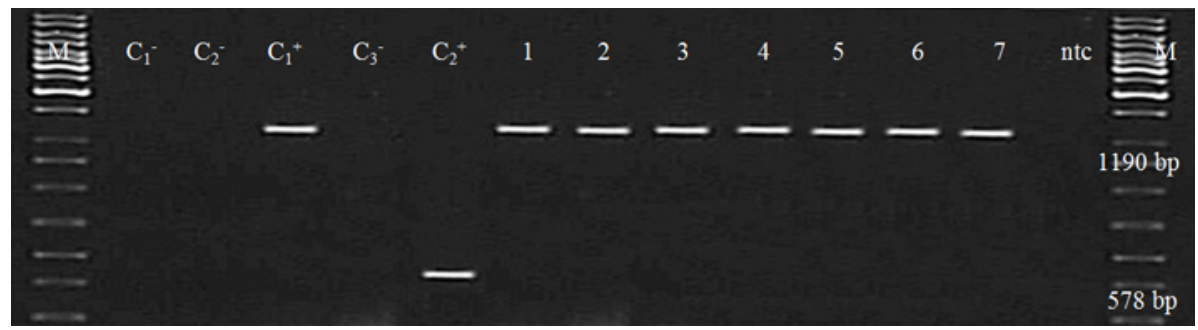

Figure 4. RT-PCR analysis of transgenic potato plants with the cry1Ab gene to evaluate gene expression at the RNA level. M: DNA ladder mix (Fermentas Company); $C_{1}^{-}$: negative control (no DNA or RNA template); $C_{2}^{-}$: sample with RNA template and without reverse transcriptase enzyme; $\mathrm{C}_{1}^{+}$: DNA template (PCR positive) and Taq polymerase; $\mathrm{C}_{3}^{-}$: RNA template and Taq polymerase enzyme; $\mathrm{C}_{2}^{+}$: control gene (human $\beta$-actin); 1-7: putative transformants; ntc: non-transgenic control. The expected fragments (1190 bp for the $c r y 1 A b$ gene and 578 bp for the $\beta$-actin gene) were amplified.
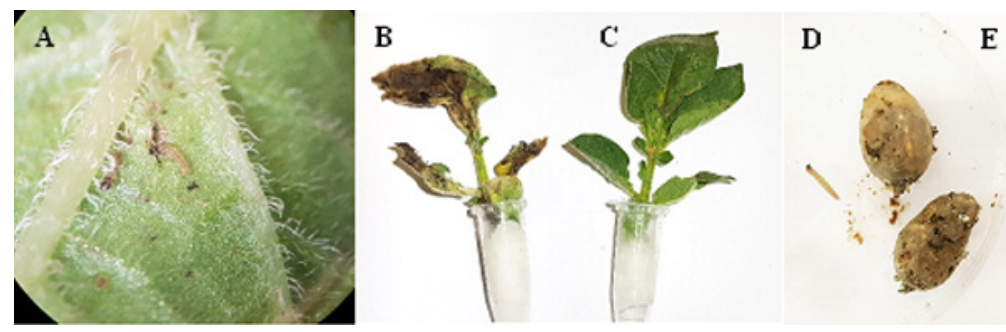

E

Figure 5. Biotoxicity assays of transgenic potatoes with PTM neonate larvae. A: neonate larvae on transgenic potato leaf; B: leaf damage on non-transgenic line compared to C: transgenic line; D: damage caused by larvae on non-transgenic tubers compared to E: transgenic tubers (after 10 days).

\section{Insect feeding assay using pot-grown foliage}

The leaves of pot-grown plants were used in laboratory bioassays with PTM larvae. Ten neonate larvae were transferred to a Petri dish containing a fully expanded terminal leaf from the pot-grown plants. Six transgenic lines with a single copy of transgene were selected for the bioassay. The results showed that all of the lines tested slowed the development and pupation of PTM larvae (Figure 5). In the detached leaf bioassay, the first mortality was after three days, but the total mortality rate was estimated after ten days. The PTM larval mortality rate on the control and transgenic leaves was $13.3 \%$ and $86.6 \%-100 \%$, respectively. The leaf damage rate after ten days ranged from $100 \%$ in non-transgenic lines to $2-8 \%$ in transgenic lines. The total weight of 10 larvae on transgenic leaves $(0.1 \mathrm{mg})$ compared to the larvae weight on control leaves $(58 \mathrm{mg}$ ) showed a significant difference after ten days of feeding (Table 1). PTM females often lay their eggs behind potato leaves, so neonates often encounter potato plant tissue at their first life stage (Davidson et al. 2004). The Cry protein content was assumed to be at the same level in excised leaves and in whole plants.

Table 1. Mortality, leaf damage, and insect biomass accumulation resulting from excised leaf bioassays of transgenic potato lines and a non-transformed control plant

\begin{tabular}{|c|c|c|c|c|c|c|c|c|}
\hline \multirow{2}{*}{$\begin{array}{l}\text { Potato } \\
\text { line }\end{array}$} & \multirow{2}{*}{$\begin{array}{l}\text { Gene copy } \\
\text { number }\end{array}$} & \multicolumn{3}{|c|}{3 days after infestation } & \multicolumn{3}{|c|}{6 days after infestation } & \multirow{2}{*}{$\begin{array}{l}\text { Protein expres- } \\
\text { sion }\end{array}$} \\
\hline & & Dead larvae & Leaf damage & $\begin{array}{l}\text { Weight of larvae } \\
\text { (mg) }\end{array}$ & Dead larvae & Leaf damage & $\begin{array}{l}\text { Weight of larvae } \\
\text { (mg) }\end{array}$ & \\
\hline PC1-9 & 1 & $5.00 \pm 1.0^{\mathrm{a}}$ & $3.67 \pm 2.3^{\mathrm{a}}$ & $0.033 \pm 0.0^{\mathrm{a}}$ & $9.33 \pm 1.1^{\mathrm{a}}$ & $5.00 \pm 0.0^{\mathrm{ab}}$ & $0.100 \pm 0.0^{\mathrm{a}}$ & Yes \\
\hline PC1-34 & 1 & $4.67 \pm 1.1^{\mathrm{a}}$ & $2.33 \pm 2.3^{\mathrm{a}}$ & $0.067 \pm 0.0^{\mathrm{a}}$ & $8.67 \pm 1.1^{\mathrm{a}}$ & $7.00 \pm 5.1^{\mathrm{ab}}$ & $0.133 \pm 0.1^{\mathrm{a}}$ & Yes \\
\hline PC1-57 & 1 & $4.33 \pm 1.1^{\mathrm{a}}$ & $2.33 \pm 2.3^{\mathrm{a}}$ & $0.033 \pm 0.0^{\mathrm{a}}$ & $9.67 \pm 0.5^{\mathrm{a}}$ & $8.33 \pm 2.8^{b}$ & $0.167 \pm 0.0^{\mathrm{a}}$ & Yes \\
\hline Control & 0 & $0.00 \pm 0.0^{b}$ & $36.67 \pm 7.6^{b}$ & $11.66 \pm 3.0^{\mathrm{b}}$ & $1.67 \pm 0.5^{b}$ & $100 \pm 0^{\mathrm{b}}$ & $58.667 \pm 16.0^{\mathrm{b}}$ & No \\
\hline
\end{tabular}

${ }_{\mathrm{a}, \mathrm{b}}$ Means $\pm \mathrm{SE}$ with different letters in the same column are significantly different at $p<.01$. 
In the present study, transgenic potato lines that significantly inhibit larval growth were considered as lines resistant to PTM. The variations in transgene expression across independently-derived transgenic plants, random integration of the transgene into different sites of the plant genome, and different numbers of insertion events for each line may be reasons for variations in resistance of transgenic plants to PTM. The results of this study confirmed that strategy used here resulted in effective management of PTM on a laboratory scale. Bioassays in the field as well as in storage facilities could be valuable further studies to confirm real PTM resistance. We suggest investigating whether these results based on greenhouse evaluations can be validated in field experimentations.

\section{ACKNOWLEDGMENTS}

We would like to thank Dr. Ghazavi from the Agricultural Entomology Research Department of IRIPP for providing the PTM eggs. The authors are very grateful to Dr. Motahareh Mohsenpour for her kind technical assistance in development of the protocols.

\section{REFERENCES}

Barrell PJ, Yongjin Sh, Cooper PA and Conner AJ (2002) Alternative selectable markers for potato transformation using minimal T-DNA vectors. Plant Cell, Tissue and Organ Culture 70: 61-68.

Beissinger A and Inglis DA (2018) Greenhouse comparison of two detection methods for potato virus $\mathrm{Y}^{\mathrm{N}-\mathrm{Wi}}$ at four potato growth stages. Plant Health Progress 19: 71-75.

Chakrabarti SK, Mandaokar AD, Shukla A, Pattanayak D, Naik PS, Sharma RP and Kumar PA (2000) Bacillus thuringiensis cry1Ab gene confers resistance to potato against Helicoverpa armigera (Hubner). Potato Research 43: 143-152.

Chattopadhyay P and Banerjee G (2018) Recent advancement on chemical arsenal of Bt toxin and its application in pest management system in agricultural field. 3 Biotech 8: 201.

Chetty VJ, Narvaez VJ and Orozco-Cardenas ML (2015) Potato (Solanum tuberosum L.). In Kang Wang (ed) Agrobacterium protocols. Methods in Molecular Biology. Springer, New York, p. 85-96.

Damalas ChA and Eleftherohorinos IG (2011) Pesticide exposure, safety issues, and risk assessment indicators. International Journal of Environmental Research and Public Health 8: 1402-1419.

Davidson MM, Jacobs JME, Reader JK, Butler RC, Frater CM, Markwick NP, Wratten SD and Conner AJ (2002) Development and evaluation of potatoes transgenic for a cry $1 A c 9$ gene conferring resistance to potato tuber moth. American Society for Horticultural Science 127: 590-596.

Davidson MM, Takla MFG, Jacobs JME, Butler RC, Wratten SD and Conner AJ (2004) Transformation of potato (Solanum tuberosum) cultivars with a $c r y 1 A c 9$ gene confers resistance to potato tuber moth (Phthorimaea operculella). New Zealand Journal of Crop and Horticultural Science 32: 39-50.

Douches DS, Li w, Zarka K, Coombs J, Pett W, Grafius E and El-Nasr T (2002) Development of Bt-cry5 insect-resistant potato lines 'Spunta-G2' and 'Spunta-G3'. HortScience 37: 1103-1107.

Estrada MA, Zarka K, Cooper S, Coombs J, Douches DS and Grafius EJ (2007) Potato tuberworm (Lepidoptera: Gelichiidae) resistance in potato lines with the Bacillus thuringiensis cry1Ac gene and natural resistance. HortScience 42: 1306-1311.

Ghareyazie, B, Alinia F, Menguito CA, Rubia LG, Palma JM, Liwanag EA, Cohen MB, Khush GS and Bennett J (1997) Enhanced resistance to two stem borers in an aromatic rice containing a synthetic crylA(b) gene. Molecular Breeding 3: 401-414

Ghasimi Hagh Z, Rahnama H, Panahandeh J, Baghban KRB, Arab Jafari KhM and Mahna N (2009) Green-tissue-specific, C4-PEPC-promoterdriven expression of cry1Ab makes transgenic potato plants resistant to tuber moth (Phthorimaea operculella, Zeller). Plant Cell Reports 28: $1869-1879$.

Guo WC, Wang ZA, Luo XL, Jin X, Chang J, He J, Tu EX, Tian YC, Si HJ and Wu JH (2016) Development of selectable marker-free transgenic potato plants expressing cry3A against the Colorado potato beetle (Leptinotarsa decemlineata Say). Pest Management Science 72: 497-504

Kamionskaya AM, Kuznetsov BB, Ismailov VY, Nadikta VD and Skryabin KG (2012) Genetically transforming Russian potato cultivars for resistance to colorado beetle. Clon Transgen 1: 1-6.

Kroschel J and Schaub B (2013) Biology and ecology of potato tuber moths as major pests of potato. In Giordanengo $P$, Vincent $C$ and Alyokhin A (eds) Insect pests of potato: Global perspectives on biology and management. Elsevier, Oxford, p. 165-192.

Kumar M, Chimote V, Singh R, Mishra GP, Naik PS, Pandey SK and Chakrabarti SK (2010) Development of Bt transgenic potatoes for effective control of potato tuber moth by using $c r y 1 A b$ gene regulated by GBSS promoter. Crop Protection 29: 121-127.

Lacey LA and Kroschel J (2006) Integrated pest management for potato tuber moth - A potato pest of global proportions. $\ln 6^{\text {th }}$ World potato congress. Idaho Potato Commission, Boise, p. 99-148.

Mehrotra M, Singh AK, Sanyal I, Altosaar I and Amla DV (2011) Pyramiding of modified $c r y 1 A b$ and cry $1 A c$ genes of Bacillus thuringiensis in transgenic chickpea (Cicer arietinum L.) for improved resistance to pod borer insect Helicoverpa armigera. Euphytica 182: 87-102.

Meiyalaghan S, Jacobs JME, Butler RC, Wratten SD and Conner AJ (2006) Expression of $c r y 1 A c 9$ and $c r y 9 A a 2$ genes under a potato light- 
inducible Lhca3 promoter in transgenic potatoes for tuber moth resistance. Euphytica 147: 297-309.

Meiyalaghan S, Pringle JM, Barrell PhJ, Jacobs JME and Conner AJ (2010) Pyramiding transgenes for potato tuber moth resistance in potato. Plant Biotechnology Reports 4: 293-301.

Mi X, Ji X, Yang J, Liang L, Si H, Wu J, Zhang N and Wang D (2015) Transgenic potato plants expressing cry3A gene confer resistance to Colorado potato beetle. Molecular biology and genetics. Comptes Rendus Bioligies 338: 443-450.

Mohammed A, Douches DS, Pett W, Grafius E, Coombs J, Liswidowati, Li W and Madkour MA (2000) Evaluation of potato tuber moth (Lepidoptera: Gelechiidae) resistance in tubers of Bt-cry5 transgenic potato lines. Journal of Economic Entomology 93: 472-476.

Murashige T and Skoog F (1962) A revised medium for rapid growth and bio assays with tobacco tissue cultures. Physiologia Plantarum 15: 473-497.

Naimow S, Dukiandjiev S and Maagd RA (2003) A hybrid Bacillus thuringiensis delta-endotoxin gives resistance against a coleopteran and a lepidopteran pest in transgenic potato. Plant Biotechnology Journal 1: 51-57.

Navarre R and Pavek MJ (2014) The potato: botany, production and uses. CABI, Boston, 383p.
Pacifico D, Musmeci S, Pulgar JS, Onofri Ch, Parisi B, Sasso R, Mandolino $G$ and Boccia GL (2019) Caffeic acid and $\alpha$-chaconine influence the resistance of potato tuber to Phthorimaea operculella (Lepidoptera: Gelechiidae). American Journal of Potato Research 96: 403-413.

Phillips T (2008) Genetically modified organisms (GMOs): Transgenic crops and recombinant DNA technology. Nature Education 1: 213

Sagredo B, Lafta A, Casper H and Lorenzen J (2006) Mapping of genes associated with leptine content of tetraploid potato. Theoretical and Applied Genetics: 131-142.

Sambrook J and Russell DW (2001) Molecular cloning: A laboratory manual. Cold Spring Harbor Laboratory Press, Cold Spring Harbor, $773 p$.

Veale MA, Slabbert MM and Van Emmenes L (2012) Agrobacteriummediated transformation of potato $\mathrm{cv}$. Mnandi for resistance to the potato tuber moth (Phthorimaea operculella). South African Journal of Botany 80: 67-74.

Vreugdenhil D, Bradshaw J, Gebhardt Ch, Govers F, Taylor M, MacKerron $\mathrm{D}$ and Ross $\mathrm{H}$ (2007) Potato biology and biotechnology: Advances and perspectives. Elsevier Science, The Netherlands, 857p.

Zhang L, Zhang X, Zhang Y, Wu S, Gelbič I, Xu L and Guan X (2016) A new formulation of Bacillus thuringiensis: UV protection and sustained release mosquito larvae studies. Scientific Reports 6: 39425. 